\section{Growth Promotion of Highbush Blueberry by Fungal and Bacterial Inoculants}

\author{
Amal de Silva ${ }^{1}$, Keith Patterson ${ }^{2}$, Craig Rothrock ${ }^{3}$, and James Moore ${ }^{4}$ \\ University of Arkansas, Fayetteville, AR 72701
}

Additional index words. rhizobacteria, Pseudomonas corrugata, Bacillus pumilus, Pseudomonas fluorescens, Gliocladium virens, Trichoderma harzianum, Vaccinium corymbosum

\begin{abstract}
The highbush blueberry cultivar Bluecrop was inoculated with potential plant growth-promoting (PGPR) candidates, including bacterial inoculants Pseudomonas fluorescens (Migula) (strains Pf 5, PRA 25, 105, or 101), Bacillus pumilus (Mayer and Gottheil) (strain T4), Pseudomonas corrugata (Roberts and Scarlett) (strain 114), and fungal isolates Gliocladium virens (Miller et al., Von Arx) (strain Gl.21) and Trichoderma harzianum (Rifai) (strain T 22). Addition of G. virens to pasteurized soil increased leaf area and the number of leaves produced in a 4-month growth period, as well as shoot content of $\mathrm{P}, \mathrm{Zn}$ and $\mathrm{Cu}$ in 1997. Treatment with $P$. fluorescens $\mathrm{Pf} 5$ increased leaf area and stem diameter. In nonpasteurized soil, plants inoculated with $G$. virens had greater leaf area, stem diameter, shoot and root dry weight, and more leaves per plant. These results demonstrate the potential of $G$. virens for increasing growth when used to inoculate blueberry plants in the nursery or at transplanting.
\end{abstract}

The blueberry industry in Arkansas has recently developed into a million dollar per year industry (Clark et al., 1989). Each year the cultivated area is increasing, especially in northwest Arkansas. Although yields per hectare are comparable with those of other blueberry producing states, production problems do exist. Blueberries in Arkansas are produced mainly on mineral soils (Moore, 1976) and in soils with high clay content (Sterne, 1982). However, blueberries are best adapted to peaty soils containing high organic matter (Eck, 1988); these do not exist in Arkansas. Phytophthora root rot has been associated with these clay soils, as well as with some mineral soils with poor drainage, and can reduce yields (Sterne, 1982).

Rhizosphere-inhabiting microorganisms interact with the root system and with each other to influence plant growth and productivity (Gaskins et al., 1985; Parke, 1990; Whipps and Lynch, 1986). Stimulatory effects of these organisms could be the result of

Received for publication 15 June 1999. Accepted for publication 14 Nov. 1999. Published with the approval of the Director, Arkansas Agricultural Experiment Station, Manuscript \# 99036. The cost of publishing this paper was defrayed in part by the payment of page charges. Under postal regulations, this paper therefore must be hereby marked advertisement solely to indicate this fact.

${ }^{1}$ Graduate Student, Dept. of Horticulture. Present address: Dept. of Plant Pathology, Ohio Agricultural Research and Development Center, Ohio State Univ., 1680 Madison Ave., Wooster, OH 44691.

E-mail address: desilva.3@osu.edu

${ }^{2}$ Associate Professor, Dept. of Horticulture. Current address: Crop Science Dept., California Polytechnic State Univ., San Luis Obispo, CA 93407. ${ }^{3}$ Professor, Department of Plant Pathology. ${ }^{4}$ Distinguished Professor, Dept. of Horticulture. biocontrol of soil-borne diseases (Keel et al., 1992; Handelsman and Stabb, 1996), production of phytohormones, or facilitation of the uptake of certain nutrients from the environment (Burr and Caesar, 1984; Glick, 1995).

Glick (1995) reported that pathogens could reduce yields by $25 \%$ to $75 \%$. Blueberry plants are grown in peat before transplanting to the field, and Moore (1979) recommended that blueberries be planted in holes filled with peat. Plant growth-promoting rhizobacteria (PGPR) increase yields of beet (Beta vulgaris L.) (Suslow and Schroth, 1982) and potato (Solanum tuberosum L.) (Frommel et al., 1993). Trichoderma sp. stimulate growth of bean (Phaseolus vulgaris L.), cucumber (Cucumis sativus L.), and pepper (Capsicum annum L.) (Inbar et al., 1994). Significantly higher dry weights of apple (Malus $\times$ domestica Borkh.) seedlings have been achieved by treating with $G$. virens (Smith et al., 1990). The objective of this study was to examine the ability of selected nonmycorrhizal or nonendophytic microorganisms to promote growth of blueberry.

\section{Materials and Methods}

Source of microorganisms. Indigenous blueberry plants were collected from Washington County, Ark. The roots were shaken to remove soil particles, weighed, submerged in $200 \mathrm{~mL}$ of sterile water, and shaken on an orbital shaker. An aliquot was serially diluted, and suspensions from the $10^{-6}$ dilutions were plated using a pour plate method in $1 / 3$ tryptic soy agar (TSA) and incubated at room temperature. Single bacterial colonies were arbitrarily selected, stored in dimethyl sulfoxide (DMSO), and frozen at $-80^{\circ} \mathrm{C}$. The bacterial isolates Pseudomonas corrugata strain 114 and $P$. fluorescens strains 105 and 101 were selected from all isolates that showed high antagonism in vitro to Phytophthora cinnamomi (Rands), a serious pathogen on blueberry in Arkansas (Sterne, 1982).

Rhizobacterial isolates $P$. fluorescens 105 and 101 were identified by the Biolog colorimetric method (similarity index 0.61 and 0.57 , respectively), using microplates (Biolog, Hayward, Calif.) and P. corrugata 114 by fatty acid profiling (similarity index 0.36) on a MIDI DOS system (Midi Labs, Newark, Del.) at the Disease Diagnostic Laboratory, Texas A\&M Univ.. Bacterial strain P. fluorescens Pf 5 was obtained from M.D. Henkels (U.S. Dept. of Agriculture, Agricultural Research Service, Horticultural Crops Research Laboratory, Corvallis, Ore.), Bacillus pumilus T4 from J.W. Kloepper (Auburn Univ., Auburn, Ala.), and $P$. fluorescens PRA 25 from J.L. Parke (Univ. of Wisconsin, Madison). The fungal candidates consisted of G. virens G1.21, (W.R. Grace and Co., Columbia, Md.) and Trichoderma harzianum $\mathrm{T} 22$ obtained from C.S. Rothrock (Univ. of Arkansas, Fayetteville).

Preparation of inoculum. The rhizobacteria were grown on V-8 agar, containing $163 \mathrm{~mL}$ of V-8 juice (Campbell Soup Co., Camden, N.J.), $2.4 \mathrm{~g}$ calcium carbonate, and $12 \mathrm{~g}$ of agar (Difco Laboratories, Detroit) per liter for $2 \mathrm{~d}$, and six loops were added to 200 $\mathrm{mL}$ of tryptic soy broth and grown at $25^{\circ} \mathrm{C}$ for $2 \mathrm{~d}$. The cultures then were centrifuged at $6800 \times g_{\mathrm{n}}$ for $20 \mathrm{~min}$ and resuspended in sterile water. The procedure was repeated. The bacterial suspensions were serially diluted and plated. Percentage of transmittance at $590 \mathrm{~nm}$ of the dilutions were read with a spectrophotometer (Bausch \& Lomb, Rochester, N.Y.), and a standard curve was obtained by plotting number of colony-forming units (cfu) against percentage of transmittance for each dilution. The bacterial candidates then were standardized using the standard curve before applying to the soil.

Inoculum of $T$. harzianum was prepared by suspending spores from 4-day-old cultures on corn meal agar (CMA) using $10 \mathrm{~mL}$ of sterile water. The spore concentration was adjusted to $10^{8}$ per $\mathrm{mL}$ by adding sterile water. Alginate pellets containing $T$. harzianum were made as follows. Sodium alginate (Sigma Chemical Co., St. Louis) was dissolved in distilled water $\left(10 \mathrm{~g} \cdot \mathrm{L}^{-1}\right)$, and corn meal (Associated Wholesale Grocers, Kansas City, Kans.) (10 g), and kaolinite (Fluka Chemika, Buchs, Switzerland) $(75 \mathrm{~g})$ were added and blended for 1 min. Spores of $T$. harzianum were added to provide a spore concentration of $10^{6} \mathrm{~mL}$, and the mixture was comminuted for $20 \mathrm{~s}$ in the blender. The prilles were formed using $0.25 \mathrm{M}$ $\mathrm{CaCl}_{2}$ (Fisher Scientific, Springfield, N.J.).

Pasteurized and nonpasteurized soil study. Field soil (Typic Hapludults) (1 kg) from the Agricultural Experiment Station, Fayetteville, Ark., was pasteurized by microwaving at $800 \mathrm{~W}$ for $4 \mathrm{~min}$ (Ferriss, 1984), and the fungal inoculum of $T$. 
harzianum or G. virens G1.21 (10 $10^{6}$ spores/g) was mixed with the soil at the rate of $1 \%$ dry weight. Bacterial treatments consisted of $B$. pumilus strain T4, $P$. fluorescens PRA 25, $P$. fluorescens $\mathrm{Pf} 5$, and the selected rhizobacteria isolated from blueberry, $P$. corrugata 114 and $P$. fluorescens strains 105 and 101 . The bacterial strains were added at the rate of $10^{6}$ to $10^{7} \mathrm{cfu} / \mathrm{g}$ of soil after transplanting, and the soil was flushed with water. The control treatment consisted of plants without any inoculations. Peters $(20 \mathrm{~N}-8.8 \mathrm{P}-16.6 \mathrm{~K})$ (United Industries Corp., St. Louis) fertilizer at the rate of $200 \mathrm{mg} \cdot \mathrm{L}^{-1}$ of nitrogen was applied each week. Nine-month-old, barerooted, uniform-sized plants of the cultivar Bluecrop (Highlander Nursery, Pettigrew. Ark.) were planted in 15-cm-diameter pots and the experiments were initiated on 4 Apr. 1996 and 8 Apr. 1997. Both experiments were conducted in a greenhouse and treatments were replicated three times in a randomized complete-block design. An additional study was done using nonpasteurized soil on 20 Apr. 1998 with G. virens and $P$. fluorescens Pf 5 in the greenhouse. These two treatments were chosen based upon the firstyear results. The control treatment was not inoculated. The treatments were replicated five times in a randomized complete-block design.

Measurements. Stem diameter and number of leaves were recorded after planting and again before harvest. Plants were harvested on 6 Aug. 1996, 10 Aug. 1997, and 22 July 1998 for the three experiments, respectively. The leaf area was measured with a leaf area meter (Lambda Institute Corp., Lincoln, Neb.). After harvest, plants were oven-dried at $80^{\circ} \mathrm{C}$ for $3 \mathrm{~d}$ and shoot and root dry weights recorded. Shoots and leaves were ground using a Wiley mill (Arthur Thomas, Philadelphia) to pass a 16 -mesh (1.02-mm pores) screen. Nutrient analysis was then determined by inductively coupled plasma atomic emission spectrometry after $\mathrm{HNO}_{3}$ digestion at the Univ. of Arkansas Altheimer Laboratory, Fayetteville.

Data analysis. The data for 1996 and 1997 were combined for analysis, as there were no interactions or treatment differences between years. Nutrient analysis was done only on the 1997 experiment. Data analysis was performed by SAS GLM procedure (SAS Institute, Cary, N.C.) and mean separation was by $\operatorname{LSD}_{0.05}$.

\section{Results}

Effects of inoculants on growth of blueberry in pasteurized soil. Treatment of blueberry plants with $G$. virens and $P$. fluorescens Pf 5 increased leaf area $\approx 60 \%$ (Table 1), whereas treatment with $T$. harzianum reduced it. Plants treated with G. virens produced 82 leaves vs. only 22 for control plants during the 4-month growing period, whereas $T$. harzianum-treated plants produced only three leaves. Increase in stem diameter of $P$. fluorescens Pf 5-treated plants was more than twice that of the control.
Effects of inoculants on dry weight. Treatment with $G$. virens or with $P$. fluorescens $\mathrm{Pf}$ 5 increased both shoot and root dry weight.

Nutrient content. Treatment with G. virens significantly increased shoot content of $\mathrm{P}$, $\mathrm{Zn}$, and $\mathrm{Cu}$ in 1997 (Table 2). Uptake of $\mathrm{Cu}$ and $\mathrm{P}$ also was increased by treatment with $P$. fluorescens PRA 25; however, N, K, Ca, and $\mathrm{S}$ content was not affected (data not shown).

Effects of inoculants on plants in nonpasteurized soil. In nonpasteurized soil, inoculation with $G$. virens increased leaf area, stem diameter, and root and shoot dry weight (Table 3 ). Inoculated plants produced 78 leaves in the 4-month growing period vs. 41 for the control plants.

\section{Discussion}

Many fungi identified as potential antagonists against plant pathogens have also been reported to enhance plant growth (Meera et al., 1994). In these studies with both pasteurized and nonpasteurized soil, G. virens stimulated the growth of blueberry plants. These results agree with those from previous work with wheat (Triticum aestivum L.) (Shivanna et al., 1994). Higher uptake of some nutrients by blueberry plants also oc- curred with application of $G$. virens and $P$. fluorescens $\mathrm{Pf} 5$, which also has been observed in wheat (de Freitas and Germida, 1992). Although P. fluorescens Pf 5 increased plant dry weights in pasteurized soil, the effects in nonpasteurized soil were nonsignificant. This could have been due to competition from natural flora, unfavorable environmental conditions, inadequate distribution of the organism (Schippers et al., 1987) or low root colonizing ability of the microorganism (Loper et al., 1984). The stimulation of growth achieved with $G$. virens treatments was greater than that obtained by addition of fertilizer. These results agree with a study done with G. roseum on tomato (Lycopersicon esculentum Mill.) by Sivapalan et al. (1994). Although the mechanism of growth promotion was not studied, it could have resulted from suppression of plant pathogens (Lumsden et al., 1992) or production of growth-regulating substances (Brown and Surgeoner, 1991). The ability of $G$. virens to grow and sporulate in natural soil is welldocumented (Lewis et al., 1996).

Blueberry plants in Arkansas are grown in peat, which is a good growth medium for a microbial inoculant, as it provides organic matter, moisture, and a suitable environment

Table 1. Effects of inoculation with microorganisms on growth of blueberry. ${ }^{\mathrm{z}}$

\begin{tabular}{lccccc}
\hline \hline & $\begin{array}{c}\text { Leaf area } \\
\left(\mathrm{cm}^{2}\right)\end{array}$ & $\begin{array}{c}\text { No. of } \\
\text { Treatment }\end{array}$ & $\begin{array}{c}\text { Increase in } \\
\text { stem diam }(\mathrm{mm})\end{array}$ & \multicolumn{2}{c}{ Dry wt $(\mathrm{g})$} \\
\cline { 3 - 6 } G. virens & $774 \mathrm{a}^{\mathrm{y}}$ & $82 \mathrm{a}$ & $0.28 \mathrm{ab}$ & $16.1 \mathrm{a}$ & Root \\
P. fluorescens Pf 5 & $748 \mathrm{a}$ & $37 \mathrm{~b}$ & $0.40 \mathrm{a}$ & $13.0 \mathrm{ab}$ & $12.7 \mathrm{a}$ \\
$P$. corrugata 114 & $589 \mathrm{ab}$ & $18 \mathrm{bc}$ & $0.23 \mathrm{ab}$ & $10.0 \mathrm{bc}$ & $7.4 \mathrm{bc}$ \\
$P$. fluorescens PRA25 & $488 \mathrm{bc}$ & $30 \mathrm{~b}$ & $0.23 \mathrm{ab}$ & $12.1 \mathrm{abc}$ & $5.7 \mathrm{bc}$ \\
$P$. fluorescens 101 & $380 \mathrm{bc}$ & $24 \mathrm{bc}$ & $0.22 \mathrm{ab}$ & $9.5 \mathrm{bc}$ & $4.0 \mathrm{c}$ \\
$P$. fluorescens 105 & $364 \mathrm{~cd}$ & $24 \mathrm{bc}$ & $0.29 \mathrm{ab}$ & $9.1 \mathrm{bc}$ & $4.8 \mathrm{c}$ \\
B. pumilus T4 & $286 \mathrm{~cd}$ & $25 \mathrm{bc}$ & $0.12 \mathrm{~b}$ & $10.2 \mathrm{bc}$ & $4.8 \mathrm{c}$ \\
T. harzianum & $153 \mathrm{~d}$ & $3 \mathrm{c}$ & $0.10 \mathrm{~b}$ & $9.3 \mathrm{bc}$ & $4.1 \mathrm{c}$ \\
Control & $470 \mathrm{bc}$ & $22 \mathrm{bc}$ & $0.09 \mathrm{~b}$ & $8.3 \mathrm{c}$ & $4.4 \mathrm{c}$ \\
\hline
\end{tabular}

${ }^{2}$ Mean of two experiments, each with three replications, one in 1996 and one in 1997. Data recorded 6 Aug. 1996 and 10 Aug. 1997.

${ }^{y}$ Mean separation within columns by LSD, $P \leq 0.05$.

Table 2. Effects of inoculation with microorganisms on total nutrient content $(\mu \mathrm{g})$ of blueberry shoots in $1997 .^{2}$

\begin{tabular}{llcr}
\hline \hline Treatment & $\mathrm{Zn}$ & $\mathrm{Cu}$ & $\mathrm{P}$ \\
\hline G. virens & $320 \mathrm{a}^{\mathrm{y}}$ & $130 \mathrm{a}$ & $16600 \mathrm{a}$ \\
$P$. fluorescens PRA 25 & $280 \mathrm{ab}$ & $100 \mathrm{ab}$ & $14200 \mathrm{ab}$ \\
$P$. fluorescens 101 & $220 \mathrm{abc}$ & $60 \mathrm{bc}$ & $9700 \mathrm{abc}$ \\
$P$. fluorescens Pf 5 & $200 \mathrm{bc}$ & $50 \mathrm{c}$ & $7600 \mathrm{bc}$ \\
B. pumilus $\mathrm{T} 4$ & $180 \mathrm{bc}$ & $60 \mathrm{bc}$ & $10500 \mathrm{abc}$ \\
$P$ fluorescens 105 & $180 \mathrm{bc}$ & $50 \mathrm{c}$ & $7900 \mathrm{abc}$ \\
$T$. harzianum & $170 \mathrm{bc}$ & $60 \mathrm{bc}$ & $10300 \mathrm{abc}$ \\
$P$. corrugata 114 & $130 \mathrm{c}$ & $40 \mathrm{c}$ & $4800 \mathrm{c}$ \\
Control & $170 \mathrm{bc}$ & $30 \mathrm{c}$ & $4100 \mathrm{c}$
\end{tabular}

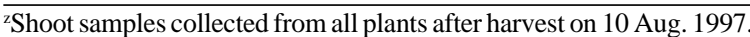

${ }^{\mathrm{y}}$ Mean separation within columns by LSD, $P \leq 0.05 . \mathrm{n}=3$.

Table 3. Effect of inoculation with microorganisms on blueberry in nonpasteurized soil.

\begin{tabular}{lccccr}
\hline \hline Treatment & $\begin{array}{c}\text { Leaf area } \\
\left(\mathrm{cm}^{2}\right)^{\mathrm{z}}\end{array}$ & $\begin{array}{c}\text { No. of } \\
\text { leaves }^{\mathrm{y}}\end{array}$ & $\begin{array}{c}\text { Stem diam } \\
(\mathrm{mm})^{\mathrm{y}}\end{array}$ & \multicolumn{2}{c}{ Dry wt $(\mathrm{g})^{\mathrm{z}}$} \\
\cline { 5 - 6 } G. virens & $759 \mathrm{a}^{\mathrm{x}}$ & $78 \mathrm{a}$ & $2.40 \mathrm{a}$ & $20.5 \mathrm{a}$ & $18.7 \mathrm{a}$ \\
$P$. fluorescens Pf 5 & $478 \mathrm{~b}$ & $27 \mathrm{~b}$ & $1.20 \mathrm{~b}$ & $13.6 \mathrm{~b}$ & $7.3 \mathrm{~b}$ \\
Control & $517 \mathrm{~b}$ & $41 \mathrm{~b}$ & $0.77 \mathrm{~b}$ & $14.0 \mathrm{~b}$ & $8.0 \mathrm{~b}$ \\
\hline
\end{tabular}

${ }^{2}$ Determined on 22 July 1998 (after harvest).

' Increase in a 4-month growing period, as determined on 20 July 1998.

${ }^{x}$ Mean separation within columns by LSD, $P \leq 0.05 . \mathrm{n}=5$. 
for establishment. We also found that treatment of blueberry plants with $G$. virens increased shoot content of nutrients essential for growth. In Arkansas, blueberry plants are transplanted into a planting hole filled with peat. The fungus could be applied in the nursery or could be added into the planting hole before transplanting. Although fungi reportedly can survive in diverse environments and in many ecological niches (Brown and Surgeoner, 1991), field studies should be undertaken to cast more light on their growthpromoting ability.

\section{Literature Cited}

Brown, A.E. and R. Surgeoner. 1991. Enhancement of plant growth by Zygorrhynchus moelleri. Ann. Appl. Biol. 118:39-46.

Burr, T.J. and A.J. Caesar. 1984. Beneficial plant bacteria. CRC Crit. Rev. Plant. Sci. 2:1-20.

Clark, J.R., D.B. Marx, and D.G. Dombek. 1989. Seasonal variation in elemental content of 'Bluecrop' blueberry leaves. Arkansas Agr. Expt. Sta. Bul. 920

de Freitas, J.R and J.J. Germida. 1992. Growth promotion of winter wheat by fluorescent pseudomonads under growth chamber conditions. Soil Biol. Biochem. 24:1127-1135.

Eck, P. 1988. Blueberry science. Rutgers Univ. Press, New Brunswick, N.J.

Ferriss, R.S. 1984. Effects of microwave oven treatment on microorganisms in soil. Phytopathology 74:121-126.

Frommel, M.I., J. Nowak, and G. Lazarovits. 1993. Treatment of potato tubers with a growth promoting Pseudomonas sp.: Plant growth responses and bacterium distribution in the rhizo- sphere. Plant and Soil. 150:51-60.

Gaskins, M.H., S.L. Albrecht, and D.H. Hubbell. 1985. Rhizosphere bacteria and their use to increase plant productivity. A review. Agr. Ecosyst. Environ. 12:99-106.

Glick, B.R. 1995. The enhancement of plant growth by free-living bacteria. Can. J. Microbiol. 41:109-117.

Handelsman, J. and E.V. Stabb. 1996. Biocontrol of plant pathogens. Plant Cell 8:1855-1869.

Inbar, J., M. Abramsky, D. Kohen, and I. Chet. 1994. Plant growth enhancement and disease control by Trichoderma harzianum in vegetable seedlings grown under commercial conditions. Eur. J. Plant. Pathol. 100:339-346.

Keel, C., U. Schnider, M. Maurhofer, C. Voisard, J. Laville, U. Burger, P. Wirthne., D. Hass, and G. Defago. 1992. Suppression of root diseases by Pseudomonas fluorescens CHAO: Importance of the bacterial secondary metabolite 2,4-diacetylphloroglucinol. Mol. Plant-Microbe Interact. 5:4-13.

Lewis, J.A., R.D. Lumsden, and J.C. Locke. 1996 Biocontrol of damping-off diseases caused by Rhizoctonia solani and Pythium ultimum with alginate prills of Gliocladium virens, Trichoderma hamatum and various food bases. Biocontrol Sci. and Tech. 6:163-173.

Loper, J.E., T.V. Suslow, and M.N. Schroth. 1984 Lognormal distribution of bacterial populations in the rhizosphere. Phytopathology 74:1454-1460.

Lumsden, R.D., J.C. Locke, S.T. Adkins, J.F. Walter, and C.J. Ridout. 1992. Isolation and localization of the antibiotic gliotoxin produced by Gliocladium virens from alginate prill in soil and soilless media. Phytopathology 82:230-235.

Meera, M.S., M.B. Shivanna, K. Kageyama, and M. Hyakumachi. 1994. Plant growth promot- ing fungi from zoysiagrass rhizosphere as potential inducers of systemic resistance in cucumbers. Phytopathology 84:1399-1406.

Moore, J.N. 1976. Adaptation and production of blueberries in Arkansas. Arkansas Agr. Expt. Sta. Bul. 804.

Moore, J. N. 1979. Highbush blueberry culture in the upper South, p. 84-86. In: J.N. Moore (ed.). Proc. Fourth N. Amer. Blueberry Res. Workers Conf., Fayetteville, Ark.

Parke, J.L. 1990. Population dynamics of Pseudomonas cepacia in the spermosphere in relation to biocontrol of Pythium. Phytopathology 80:1307-1311.

Schippers, B., A.W. Bakker, and P.A.H.M. Bakker. 1987. Interactions of deleterious and beneficial rhizosphere microorganisms and the effect of cropping practices. Annu. Rev. Phytopathol. 25:339-358.

Shivanna, M., M.S. Meera, and M. Hyakumachi. 1994. Sterile fungi from zoysiagrass as plant growth promoters in spring wheat. Can. J. Microbiol. 40:637-644.

Sivapalan A., W.C. Morgan, and P.R. Franz. 1994. Effect of inoculating fungi into compost on growth of tomato and compost microflora. Aust. J. Expt. Agr. 34:541-548.

Smith, V.L., W.F. Wilcox, and G.E. Harman. 1990. Potential for biological control of Phytophthora root and crown rots of apple by Trichoderma and Gliocladium sp. Phytopathology 80:880-885.

Sterne, R.E. 1982. Phytophthora root rot of blueberry in Arkansas. Plant Dis. 66:604-605.

Suslow, T.V. and M.N. Schroth. 1982. Rhizobacteria of sugarbeet: Effects of seed application and root colonization on yield. Phytopathology 72:199-206.

Whipps, J.M. and J.M. Lynch. 1986. The influence of rhizosphere on crop productivity. Adv. Microbiol. Ecol. 9:187-244. 